\title{
PENGEMBANGAN DESAIN PEMBELAJARAN BERBASIS PENEMUAN TERBIMBING UNTUK MENINGKATKAN KEMAMPUAN BERPIKIR KRITIS MATEMATIS
}

\author{
Sri Handayani ${ }^{1}$, Caswita $^{2}$, Nurhanurawati ${ }^{3}$ \\ 1,2,3 Prodi Magister Matematika, FKIP, Universitas Lampung, Jl.Prof. Dr. Sumantri Brojonegoro No.1 Gedong \\ Meneng, Bandar Lampung, Indonesia \\ srihandayanii007@gmail.com
}

\begin{abstract}
To solve the problem of student's low mathematical critical thinking skills, it is necessary to have an innovation in the learning process. This development research aims to develop a learning design based on guided discovery-based to improve valid and practical mathematical critical thinking skills. This type of research is development research using the Tessmer model, which is limited to expert review stage. This development stage starts from the preliminary stage (preparation and design stage), the self-evaluation stage, and the expert review stage. The research was conducted at SMA Kebangsaan Lampung in the Odd Semester of Academic Year 2020/2021. Collecting data were through observation, interviews, and questionnaires. Learning designs and learning media were validated by design experts, material experts, and education practitioners. Furthermore, the design and learning media were revised according to the opinion of the experts. Learning designs and learning media were validated by 2 design and material experts, 2 teacher practitioners and 5 student practitioners. The results of the validation of the experts showed that the learning tools and designs were feasible to use and implemented after meeting the valid and practical criteria. This can be seen from the results of the validator's assessment which has valid criteria and the category is very practical.
\end{abstract}

Keywords: Guided Discovery, Instructional Design, Mathematical Critical Thinking Tessmer's Model.

\begin{abstract}
Abstrak
Untuk menyikapi permasalahan rendahnya kemampuan berpikir kritis matematis siswa, diperlukan adanya inovasi proses pembelajaran. Penelitian pengembangan ini bertujuan untuk mengembangkan desain pembelajaran berbasis penemuan terbimbing untuk meningkatkan kemampuan berpikir kritis matematis yang valid dan praktis. Jenis penelitian ini adalah penelitian pengembangan menggunakan model Tessmer.yang bersifat terbatas hingga tahapan expert review. Tahapan pengembangan ini dimulai dari tahap preliminary (tahap persiapan dan pendesainan), tahap self evaluation, dan tahap expert review. Penelitian dilaksanakan di SMA Kebangsaan Lampung pada Semester Ganjil Tahun Pelajaran 2020/2021. Pengumpulan data melalui observasi, wawancara, dan angket. Validasi desain pembelajaran dan perangkat pembelajaran oleh ahli desain, ahli materi, dan praktisi pendidikan. Selanjutnya desain dan perangkat pembelajaran direvisi sesuai pendapat para ahli. Desain pembelajaran dan perangkat pembelajaran divalidasi oleh 2 pakar ahli desain dan materi, 2 praktisi guru dan 5 praktisi siswa. Hasil validasi para ahli diperoleh bahwa perangkat pembelajaran dan desain layak digunakan dan diimplementasikan setelah memenuhi kriteria valid dan praktis. Hal ini dapat dilihat dari hasil skor penilaian validator adalah diatas yang memiliki kriteria valid dan kategori sangat praktis.
\end{abstract}

Kata Kunci: Penemuan Terbimbing, Desain Pembelajaran, Berpikir Kritis Matematis, Model Tessmer.

\section{PENDAHULUAN}

Pendidikan mempunyai peranan penting dalam mempersiapkan manusia yang mampu bersaing di era global. Pentingnya pendidikan ini didukung dengan perumusan fungsi pendidikan nasional oleh pemerintah melalui Undang-Undang Nomor 20 Pasal 3 (Depdiknas, 2003), bahwa pendidikan nasional berfungsi mengembangkan kemampuan dan membentuk watak serta peradaban bangsa yang bermartabat dalam rangka mencerdaskan kehidupan bangsa, bertujuan untuk mengembangkan potensi peserta didik agar menjadi manusia yang beriman dan bertakwa kepada Tuhan Yang Maha Esa, berakhlak mulia, sehat, berilmu, cakap, kreatif, mandiri, dan menjadi warga negara yang demokratis serta bertanggung jawab.

Karakteristik matematika yang memuat simbol, lambang, tabel, dan grafik membuat banyak 
siswa Indonesia berpikir bahwa matematika adalah pelajaran yang sulit. Data kemendikbud tahun 2019 rata-rata nilai Ujian Nasional matematika untuk program IPA di Lampung yaitu 36,18 dan nilai tersebut merupakan peringkat kedelapan belas dari 34 provinsi di Indonesia (Kemdikbud, 2019). Hal tersebut menunjukkan bahwa kemampuan berpikir kritis matematis siswa di Lampung masih tergolong rendah. Rendahnya kemampuan matematis siswa di Indonesia dapat dipengaruhi oleh beberapa faktor. Salah satu faktor yang mempengaruhi adalah kurangnya siswa melatih kemampuan berpikir kritisnya dalam menyelesaikan soal cerita yang mengandung masalah kontekstual. Beberapa soal matematika yang digunakan UN merupakan jenis soal cerita, sehingga siswa diharuskan dapat memahami maksud soal tersebut untuk menentukan penyelesaiannya. Apabila kemampuan berpikir kritis matematis siswa kurang baik maka siswa akan kesulitan untuk menerjemahkan maksud soal tersebut.

Untuk menyikapi permasalahan rendahnya kemampuan berpikir kritis matematis siswa, diperlukan adanya inovasi proses pembelajaran. Inovasi yang dilakukan ini diharapkan mampu untuk menciptakan suasana belajar yang nyaman dan mampu memotivasi siswa untuk terus belajar, sehingga siswa mampu mengembangkan kemampuan kemampuan berpikir kritis matematisnya. Proses pembelajaran yang seperti itu dapat tercipta apabila guru mampu mendesain pembelajaran yang tepat sehingga mampu meningkatkan kemampuan berpikir kritis matematis siswa. (Sagala, 2005) mengungkapkan desain pembelajaran adalah pengembangan pengajaran secara sistematik yang digunakan secara khusus teori-teori pembelajaran untuk menjamin kualitas pembelajaran.

Mengajarkan siswa dengan menemukan sebuah gagasan, pemikiran yang kritis, pertanyaan, dan kemampuan penyelesaian masalah adalah satu dari prinsip utama pembelajaran sains dan teknologi. Dengan demikian, pembelajaran sains dan teknologi seharusnya berdasarkan pengembangan. Untuk mendidik peserta didik dapat menyelidiki dan mnyelesaikan masalah yang mereka hadapi. Saat ini, dipercaya bahwa metode dengan pendekatan kontruksivis membuat siswa belajar lebih efektif dengan membangun pengetahuan mereka sendiri. Salah satu metode ini adalah pembelajaran penemuan (Balım, 2009).

Dalam metode ini, siswa didorong untuk berpikir sendiri sehingga dapat menemukan prinsip umum berdasarkan bahan atau data yang telah disediakan oleh guru. Dengan pendekatan penemuan terbimbing ini, diharapkan dapat mengubah gaya belajar siswa sehingga siswa menjadi aktif dalam mengikuti pelajaran, sampai seberapa jauh siswa dibimbing, tergantung pada kemampuannya dan materi yang sedang dipelajari.

Berpikir kritis adalah sebuah proses terorganisasi yang memungkinkan siswa mengevaluasi bukti, asumsi, logika, dan bahasa yang mendasari pernyataan orang lain. Berpikir kritis adalah berpikir dengan baik dan teliti. Uraian tersebut selaras dengan pernyataan Dewey (Alec, 2007), bahwa berpikir kritis adalah pertimbangan aktif, persistent (terus-menerus), dan teliti mengenai sebuah keyakinan atau bentuk pengetahuan yang diterima begitu saja dipandang dari sudut alasan-alasan 
yang mendukungnya dan kesimpulan-kesimpulan lanjutan yang menjadi kecenderungannya.

Menurut Halpen (Susanto, 2013), "berpikir kritis adalah memberdayakan keterampilan atau strategi kognitif dalam menentukan tujuan". Proses tersebut dilalui setelah menentukan tujuan, mempertimbangkan, mengacu langsung kepada sasaran. Berpikir kritis merupakan bentuk berpikir yang perlu dikembangkan dalam rangka memecahkan masalah, merumuskan kesimpulan, mengumpulkan berbagai kemungkinan, dan membuat keputusan ketika menggunakan semua keterampilan tersebut secara efektif dalam konteks dan tipe yang tepat. Berpikir kritis juga merupakan kegiatan mengevaluasi, mempertimbangkan kesimpulan yang akan diambil manakala menentukan beberapa faktor pendudukung untuk membuat keputusan. Berpikir kritis juga bisa disebut directed thinking, sebab berpikir langsung kepada fokus yang ditunggu.

Berdasarkan pendapat-pendapat diatas maka pada penelitian ini, peneliti mengembangkan desain pembelajaran berbasis penemuan terbimbing dengan memberikan masalah kontekstual berbasis kearifan lokal pada salah satu sintak dari pembelajaran penemuan untuk melatih siswa agar memiliki kemampuan dalam pemecahan masalah serta untuk memperoleh pengetahuan dan pemahaman konsep matematika untuk diterapkan dalam kehidupan sehari-hari.

\section{METODE}

Jenis penelitian ini adalah penelitian pengembangan atau dikenal juga sebagai Research and Development (R\&D) model Tessmer melalui beberapa modifikasi. Penelitian dan pengembangan yang akan dilakukan pada penelitian ini adalah Pengembangan Desain berbasis penemuan terbimbing yang dapat meningkatkan kemampuan berpikir kritis matematis siswa.

\section{Subjek Penelitian}

Penelitian ini dilaksanakan di SMA Kebangsaan Lampung yang berada di Kecamatan Penengahan Kabupaten Lampung Selatan pada semester ganjil tahun pelajaran 2020/2021. Subjek dalam penelitian ini ada dua yaitu subjek studi pendahuluan dan subjek validasi pengembangan.

\section{Prosedur Penelitian}

Penelitian pengembangan ini dilakukan dengan mengacu pada prosedur Research \& Development dari (Tessmer, 1993) melalui beberapa modifikasi. Adapun alur desain penelitian pengembangan ini dijelaskan sebagai berikut

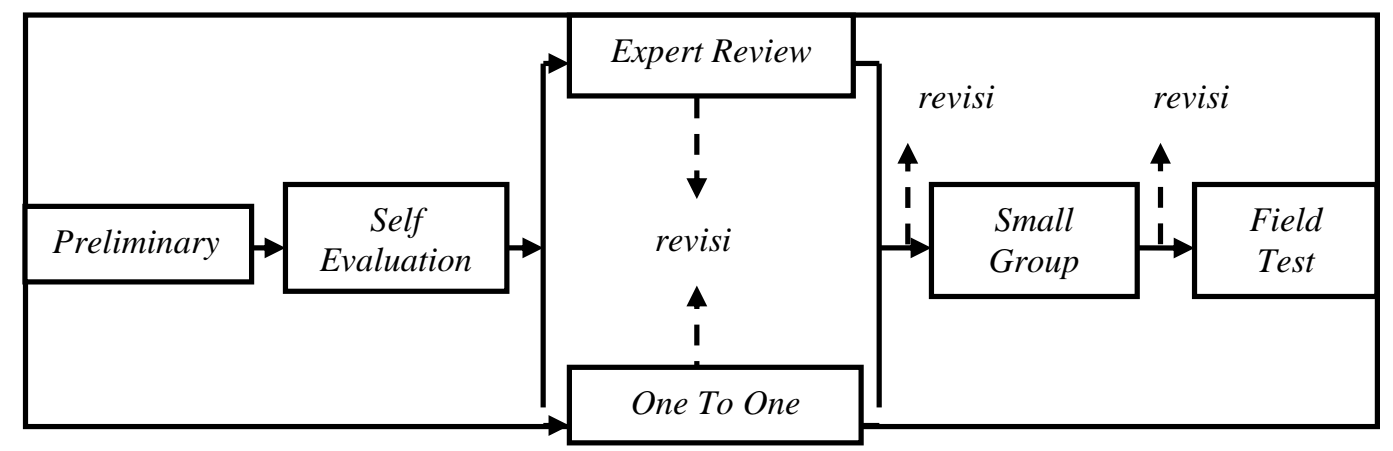

Gambar 1 Skema prosedur penelitian 
Penelitian pengembangan ini bersifat terbatas, tahapan $R \& D$ hanya dilakukan hingga tahapan expert review. Pembatasan tahapan R\&D ini dilakukan karena merujuk pada surat edaran Dekan FKIP Universitas Lampung nomor: 1980/UN26.13/PP.03.02/2020 Tentang Penyelesaian Penelitian Pengembangan terbatas sampai tahap validasi ahli dan dilaksanakan sesuai protokol darurat pencegahan penyebaran virus covid-19 dan mengingat keterbatasan waktu dalam menyelesaikan penelitian pengembangan ini. Langkah penelitian dan pengembangan yang dilakukan adalah sebagai berikut:.

\section{Tahap Preliminary}

Tahap ini dibagi menjadi dua yakni tahap persiapan dan tahap pendesainan. Pada tahap persiapan, peneliti melakukan analisis materi dan tujuan pembelajaran. Pada tahap desain, peneliti melakukan pendesainan pembelajaran yang dikembangkan. Produk yang dihasilkan dinamakan prototype 1.

\section{Tahap formative evaluation}

Pada tahap ini dilaksanakan beberapa tahapan sebagai berikut: (1) self evaluation. Pada tahap ini dilakukan penilaian diri sendiri terhadap hasil pengembangan pembelajaran; (2) expert review atau uji ahli. Hasil desain pada prototype 1 yang dikembangkan atas dasar self evaluation diberikan kepada ahli. Saran-saran dari ahli digunakan untuk merevisi desain pengembangan program pembelajaran; (3) one to one. Pada tahap ini dilakukan ujicoba kepada beberapa orang siswa untuk hasil prototype 1. Hasil validasi dan saran serta hasil uji coba yang diperoleh pada tahap ini dijadikan bahan untuk merevisi hasil prototype 1. Hasil revisi dinamakan prototype 2.

\section{Instrumen Penelitian}

Instrumen yang digunakan dalam penelitian ini berdasarkan tahapan penelitian pengembangan. Uraian instrumen yang digunakan pada penelitian adalah:.

\section{Instrumen Studi Pendahuluan}

Instrumen yang digunakan berupa lembar observasi dan wawancara. Studi pendahuluan dilakukan sebelum dilaksanakan penelitian untuk melihat masalah yang terjadi di lapangan. Studi ini diawali dengan melakukan observasi di kelas dilanjutkan wawancara kepada guru mata pelajaran untuk memperjelas hasil observasi. Pada observasi di kelas, peneliti melihat proses pembelajaran matematika yang berlangsung oleh guru bidang studi dan juga siswa. Selanjutnya, dilakukan wawancara dengan beberapa siswa.

\section{Instrumen Validasi Ahli}

Instrumen dalam validasi desain pembelajaran berbasis penemuan terbimbing diserahkan kepada ahli materi, media, dan praktisi. Instrumen yang diberikan berupa pernyataan skala likert dengan empat pilihan jawaban, yaitu sangat baik, baik, kurang, dan sangat kurang, serta di lengkapi komentar dan saran dari para ahli.

\section{Angket uji validasi materi}

Instrumen ini digunakan untuk menguji substansi perangkat pembelajaran yang digunakan dalam penelitian. Perangkat yang diuji diantaranya silabus, RPP, LKPD, dan instrumen tes berpikir kritis. 
Instrumen ini meliputi kesesuaian indikator dengan Kompetensi Inti (KI) dan Kompetensi Dasar (KD). Instrumen diisi oleh pakar matematika.

Angket Uji Validasi Media

Instrumen ini digunakan untuk menguji substansi LKPD sebagai media pembelajaran yang digunakan dalam penelitian. Instrumen ini berisi angket tentang kelayakan kegrafisan dan bahasa yang didalamnya memuat ukuran, desain isi, kelugasan, kekomunikatifan, kesesuaian dengan kaidah bahasa, dan penggunaan istilah.

\section{Angket Validasi Praktisi}

Instrumen ini digunakan untuk mengetahui tanggapan praktisi tentang produk yang dikembangkan. Substansi yang diuji yaitu, silabus, RPP, LKPD, dan instrumen tes berpikir kritis.

\section{HASIL}

Hasil pengembangan ini berupa desain pembelajaran berbasis penemuan terbimbing yang berwujud perangkat pembelajaran yang tertuang pada LKPD.

\section{Hasil Validasi Produk Pengembangan}

Validasi ahli materi dilakukan untuk menguji kevalidan materi/isi dan penyajiannya dalam pembelajaran. Validasi ahli desain dilakukan untuk menguji kevalidan desain pembelajaran dengan melihat komponen konstruksi dan teknisnya. Validasi dilakukan oleh ahli materi dan desain yakni dosen Universitas Teknokrat Indonesia, yaitu Ibu Nicky Dwi Puspaningtyas, S.Pd., M.Pd. (validator I) dan Dosen UIN Raden Intan Lampung yaitu Ibu Avissa Purnama Yanti, M.Pd. (validator II). Produk yang dinilai oleh validator adalah Silabus, RPP, LKPD, dan instrumen tes berpikir kritis.

Validasi praktisi digunakan untuk mengetahui respon dan tanggapan dari Guru matematika dan 5 siswa. Peneliti meminta tanggapan dari Ibu Awit Febriansari, S.Pd dan Ibu Khumairoh, S.Pd yang merupakan guru matematika di SMA Kebangsaan Lampung. Tanggapan guru matematika berupa penilaian terhadap silabus, RPP, dan LKPD. Adapun hasil dari penilaian validator diperoleh sebagai berikut

\section{Tabel 1.}

Hasil Perolehan Skor Validasi Ahli Materi

\begin{tabular}{|l|c|c|c|c|}
\hline \multicolumn{1}{|c|}{ Produk } & $\begin{array}{c}\text { Validator I } \\
(\mathbf{\%})\end{array}$ & $\begin{array}{c}\text { Validator II } \\
(\boldsymbol{\%})\end{array}$ & $\begin{array}{c}\text { Rata-rata } \\
(\mathbf{\%})\end{array}$ & Kesimpulan \\
\hline Silabus & 92,50 & 82,50 & 87,50 & Dapat digunakan dengan revisi \\
\hline RPP & 91,67 & 83,33 & 87,50 & Dapat digunakan dengan revisi \\
\hline LKPD & 88,51 & 84,46 & 86,49 & Dapat digunakan dengan revisi \\
\hline Instrumen Tes & 92,31 & 84,62 & 88,47 & Dapat digunakan dengan revisi \\
\hline
\end{tabular}


Tabel 2.

Hasil Perolehan Skor Validasi Ahli Desain

\begin{tabular}{|l|c|c|c|c|}
\hline \multicolumn{1}{|c|}{ Aspek yang Disajikan } & $\begin{array}{c}\text { Validator I } \\
(\mathbf{\%})\end{array}$ & $\begin{array}{c}\text { Validator II } \\
(\mathbf{\%})\end{array}$ & $\begin{array}{c}\text { Rata-rata } \\
(\mathbf{\%})\end{array}$ & Kesimpulan \\
\hline $\begin{array}{l}\text { - Teori Pendukung } \\
\text { - Isi yang Disajikan } \\
\text { - Hasil Belajar yang } \\
\text { Diinginkan }\end{array}$ & 90,63 & 81,25 & 85,94 & $\begin{array}{l}\text { Layak digunakan } \\
\text { dengan revisi }\end{array}$ \\
\hline
\end{tabular}

Tabel 3.

Hasil Perolehan Skor Respon Praktisi Guru

\begin{tabular}{|l|c|c|c|l|}
\hline Produk & $\begin{array}{c}\text { Praktisi II } \\
(\mathbf{\%})\end{array}$ & $\begin{array}{c}\text { Praktisi II } \\
(\mathbf{\%})\end{array}$ & $\begin{array}{c}\text { Rata-rata } \\
(\mathbf{\%})\end{array}$ & Kesimpulan \\
\hline Silabus & 97,50 & 87,50 & 92,50 & Dapat digunakan tanpa revisi \\
\hline RPP & 93,75 & 89,58 & 91,67 & Dapat digunakan tanpa revisi \\
\hline LKPD & 97,92 & 90,63 & 94,28 & Dapat digunakan tanpa revisi \\
\hline
\end{tabular}

Secara keseluruhan berdasarkan kesimpulan produk termasuk dalam kategori valid, sangat praktis dan dapat digunakan tanpa revisi.

\section{Hasil Revisi Uji Ahli}

Revisi perangkat pembelajaran penemuan terbimbing dilakukan berdasarkan saran dan masukan dari para ahli materi dan ahli desain. Hasil revisi dikonsultasikan kembali kepada ahli sampai diperoleh perangkat pembelajaran yang dikatakan layak dan siap diuji cobakan. Dari saran yang diberikan oleh ahli, dilakukan beberapa perbaikan sebagai berikut.

\section{Revisi RPP}

RPP disarankan pada kegiatan pendahuluan diberikan apersepsi. Perbaikan dilakukan dengan menambahkan apersepsi pada kegiatan pendahuluan dapat dilihat pada Gambar 2.

\section{Revisi LKPD}

LKPD disarankan pada judul dituliskan KD dan IPK agar tujuan pembelajaran terlihat jelas. Perbaikan dilakukan dengan menuliskan KD dan IPK yang dapat dilihat pada Gambar 3.

Pembahasan penelitian ini dilakukan berdasarkan tahapan-tahapan pada penelitian pengembangan yang dimulai dari pengembangan desain pembelajaran penemuan terbimbing sampai dengan uji ahli dan uji praktisi untuk melihat apakah perangkat pembelajaran yang dikembangkan layak digunakan. Berdasarkan hal diatas maka produk yang ingin dikembangkan berupa perangkat pembelajaran dengan desain pembelajaran penemuan terbimbing. Dimulai dengan membuat draf produk awal memuat komponen sintak pembelajaran, silabus, RPP, LKPD, dan perangkat pembelajaran lain yang mendukung.

Langkah berikutnya adalah validasi ahli. Pengembangan desain pembelajaran berbasis penemuan 
terbimbing berupa perangkat pembelajaran yang telah disusun kemudian diserahkan kepada ahli agar dapat divalidasi. Penilaian dari ahli materi $87,50 \%$ untuk silabus, sedangkan untuk RPP memperoleh 87,50\%. Dari hasil penilain tersebut maka Silabus dan RPP yang digunakan termasuk dalam kategori baik. Penilaian LKPD dari ahli materi memperoleh 86,49\%, dengan demikian LKPD yang digunakan termasuk dalam kategori valid.

Konsep yang termuat dalam LKPD akan membimbing siswa untuk mengkontruksi pemahamannya terhadap materi yang sedang dipelajari. Agar kemampuan pemahaman berpikir kritis matematis siswa dapat lebih dikembangkan, maka diberikan latihan soal-soal yang memuat indikator kemampuan berpikir kritis. Dalam hal ini pengembangan desain pembelajaran berbasis penemuan terbimbing diharapkan dapat menjadi alternatif untuk meningkatkan hasil belajar terutama kemampuan berpikir kritis matematis.

\begin{tabular}{|c|c|c|}
\hline \multicolumn{3}{|c|}{$\begin{array}{l}\text { Langkah - Langkah Kegiat: } \\
\text { Pertemuan ke-1 ( } 2 \text { x } 45 \text { menit) }\end{array}$} \\
\hline $\begin{array}{c}\text { Tahapan/ } \\
\text { Sintak }\end{array}$ & $\begin{array}{c}\text { Uraian } \\
\text { Kegiatan Pembelajaran }\end{array}$ & $\begin{array}{l}\text { Nilal-Nilat } \\
\text { Karakter }\end{array}$ \\
\hline (1) & (2) & (3) \\
\hline \multicolumn{3}{|c|}{ Pendahuluan (10 menit) } \\
\hline & $\begin{array}{l}\text { 1. Guru mengucapkan salam. } \\
\text { 2. Guru mengondisikan kelas dan meminta ketua } \\
\text { kelas memimpin doa. } \\
\text { 3. Guru menanyakan kabar dan memeriksa } \\
\text { kehadiran peserta didik. } \\
\text { 4. Guru menyampaikan kompetensi yang akan } \\
\text { dicapai dan manfaat mempelajari materi sistem } \\
\text { persamaan linear tiga variabel dalam kehidupan } \\
\text { sehari-hari di antaranya untuk menentukan laba, } \\
\text { menentukan harga pokok suatu barang, } \\
\text { membandingkan harga, dan sebagainya. } \\
\text { 5. Guru menyampaikan lingkup dan teknik } \\
\text { penilaian yang akan digunakan. } \\
\text { 6. Guru membagi peserta didik ke dalam } \\
\text { kelompok kecil yang terdiri dari } 4-5 \text { orang. } \\
\text { 7. Guru membagikan LKPD } 1 \text {. }\end{array}$ & $\begin{array}{c}\text { Tanggung } \\
\text { jawab }\end{array}$ \\
\hline
\end{tabular}

\begin{tabular}{|c|c|c|}
\hline $\begin{array}{c}\text { Tahapan/ } \\
\text { Sintak }\end{array}$ & $\begin{array}{c}\text { Uraian } \\
\text { Keglatan Pembelajaran }\end{array}$ & $\begin{array}{l}\text { Nilai-Nilal } \\
\text { Karakter }\end{array}$ \\
\hline (1) & (2) & (3) \\
\hline \multicolumn{3}{|c|}{ Pendahuluan (10 menit) } \\
\hline & $\begin{array}{l}\text { 1. Guru mengucapkan salam. } \\
\text { 2. Guru mengondisikan kelas dan meminta ketua } \\
\text { kelas memimpin doa. } \\
\text { 3. Guru menanyakan kabar dan memeriksa } \\
\text { kehadiran peserta didik. } \\
\text { 4. Guru memberikan apersepsi dengan } \\
\text { mengingatkan kembali peserta didik mengenai } \\
\text { materi sistem persamaan linear dua variabel. } \\
\text { 5. Guru menyampaikan kompetensi yang akan } \\
\text { dicapai dan manfaat mempelajari materi sistem } \\
\text { persamaan linear tiga variabel dalam kehidupan } \\
\text { sehari-hari di antaranya untuk menentukan laba, } \\
\text { menentukan harga pokok suatu barang, } \\
\text { membandingkan harga, dan sebagainya. } \\
\text { 6. Guru menyampaikan lingkup dan teknik } \\
\text { penilaian yang akan digunakan. } \\
\text { 7. Guru membagi peserta didik ke dalam } \\
\text { kelompok kecil yang terdiri dari } 4-5 \text { orang. } \\
\text { 8. Guru membagikan LKPD } 1 .\end{array}$ & $\begin{array}{c}\text { Tanggung } \\
\text { jawab }\end{array}$ \\
\hline
\end{tabular}

Gambar 2. RPP sebelum dan setelah revisi ahli materi
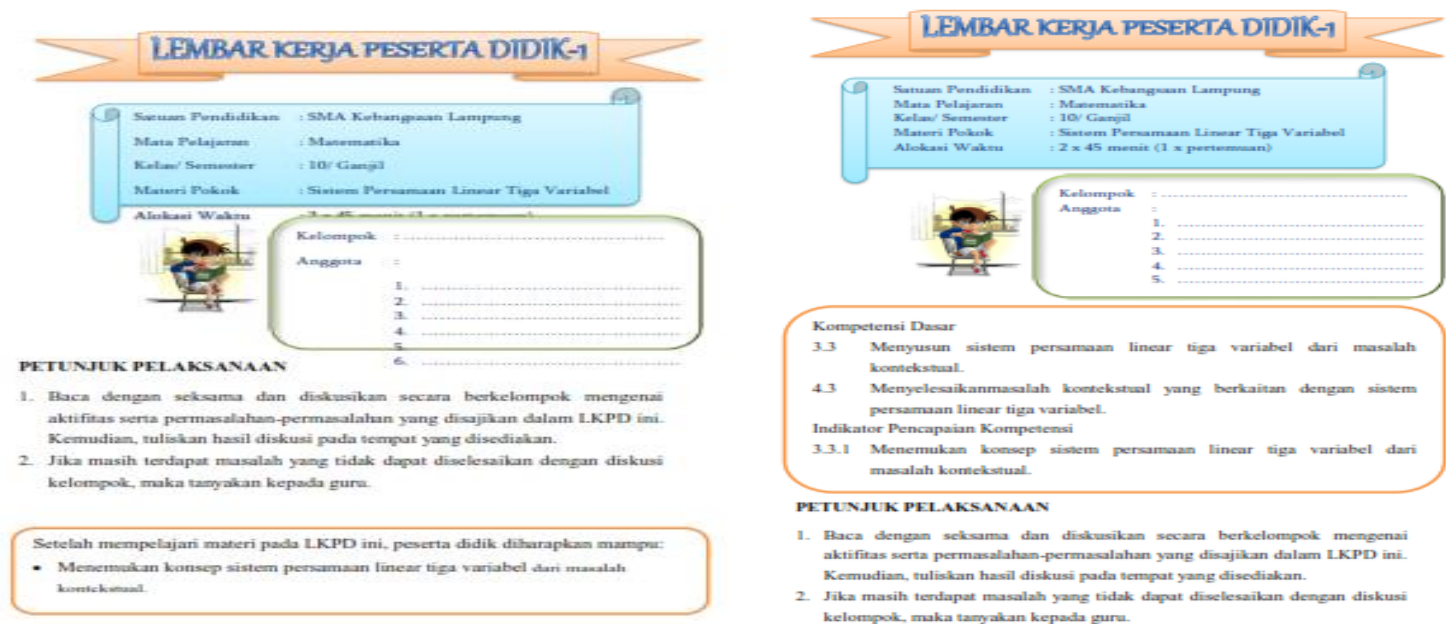

Gambar 3. LKPD Sebelum Dan Setelah Revisi Ahli Materi 


\section{KESIMPULAN}

Berdasarkan hasil analisis data dan pembahasan, diperoleh kesimpulan sebagai berikut:

1. Hasil pengembangan yang berupa perangkat pembelajaran dengan desain pembelajaran berbasis penemuan terbimbing menunjukkan bahwa layak digunakan dan termasuk dalam kategori baik dan praktis. Hal ini dapat dilihat dari hasil validasi ahli media, materi dan praktisi.

2. Hasil akhir dari penelitian pengembangan ini adalah tersusun produk berupa perangkat pembelajaran dengan desain pembelajaran berbasis penemuan terbimbing yang dapat meningkatkan kemampuan berpikir kritis matematis siswa.

\section{DAFTAR PUSTAKA}

Alec, F. (2007). Berpikir Kritis Sebuah Pengantar. Erlangga.

Balım, A. G. (2009). The Effects of Discovery Learning on Students' Success and Inquiry Learning Skills. Eurasian Journal of Educational Research.

Depdiknas. (2003). Undang-Undang No. 20 Tahun 2003, tentang Sistem Pendidikan Nasional. Depdiknas.

Kemdikbud. (2019). Capaian Nilai Ujian Nasional. https://hasilun.puspendik.kemdikbud.go.id/\#2019!sma!capaian!99\&99\&999!a\&T\&T\&T\&1\&!1! $\&$

Markaban. (2008). Model Penemuan Terbimbing Pada Pembelajaran Matematika SMK. Pusat Pengembangan dan Pemberdayaan Pendidikan dan Tenaga Kependidikan Matematika.

Roestiyah. (2012). Strategi Belajar Mengajar. Rineka Cipta.

Sagala, S. (2005). Konsep dan Makna Pembelajaran. Alfabeta.

Sugiyono. (2010). Statistika Untuk Penelitian. Alfabeta.

Susanto, A. (2013). Teori Belajar Dan Pembelajaran Di Sekolah Dasar. Kencana Prenada Media Group.

Tessmer, M. (1993). Planning and Conducting Formative Evaluations: Improving the Quality of Education and Training. Kogan Page.

Trianto. (2007). Model-Model Pembelajaran Inovatif Berorientasi Kontruktivistik. Prestasi Pustaka. 